\title{
Towards nearly zero-energy residential neighbourhoods in the European Union: A case study
}

\author{
Modeste Kameni Nematchoua $^{\text {a,b, }}$, Antoinette Marie-Reine Nishimwe ${ }^{\mathrm{b}}$, Sigrid Reiter ${ }^{\mathrm{b}}$ \\ ${ }^{a}$ Beneficiary of an AXA Research Fund Post-doctoral Grant, Research Leaders' Fellowships, AXA SA 25 Avenue Matignon, 75008, Paris, France \\ ${ }^{\mathrm{b}}$ LEMA, Urban and Environmental Engineering Department, Liege University, Allée de La Découverte9 (B52), Quartier Polytech 1, 4000, Liege, Belgium
}

\section{A R T I C L E I N F O}

\section{Keywords:}

Nearly zero-energy communities

District

Cities

Forecast scenarios

Transport

\begin{abstract}
A B S T R A C T
The European Union (EU) aims to establish a guideline that requires all new buildings to comply with nearly zero-energy buildings (NZEB) by 2030. This decision involves new technologies based on concepts that meet international standards. This research aims to review the literature on 'net zero-energy building' and analyses the possibility of applying this research on nine statistically representative neighbourhoods of the building stock'in Belgium, depending on the built density. All the areas, grouped into four categories (urban, peri-urban, suburban, and rural neighbourhoods), were used for current energy consumption analysis and to evaluate prospective scenarios based on four major challenges, namely climate change, building renovations, photovoltaic panels, and sustainable mobility. In addition, a new approach combining several scenarios to further improve energy needs at the neighbourhood scale is also highlighted. The nine different types of neighbourhoods studied are commonly found in different countries across the EU. The average reduction in energy consumption of neighbourhoods (buildings + daily mobility) in 2040 (compared to reference year 2012) will likely reach 5.69\% attributable to a $20 \%$ reduction in distances travelled, $6.48 \%$ to climate change, $12.95 \%$ to the current annual buildings renovation rate, $18.76 \%-100 \%$ electric cars, $22.26 \%$ for doubling the current buildings renovation rate, $31.62 \%$ and $63.25 \%$ to a light or heavy renovation of the entire building stock, respectively. Moreover, installing $20 \mathrm{~m}^{2}$ of solar panels on the rooftops of each residential building would produce renewable energy equivalent to $6.53 \%$ of the current global energy consumption. Finally, the results show that more than $90 \%$ of current energy consumption can be reduced at the neighbourhood scale (buildings + daily mobility) by combining a heavy renovation of all the buildings, electric vehicles, and photovoltaic panels. This scenario allows reaching the 'nearly zero-energy' target at the neighbourhood scale.
\end{abstract}

\section{Introduction}

Population growth has increased the demand for heating energy in various habitats and climates, as a result buildings are becoming one of the most energy intensive sectors [1,2]. This situation is multiplying tensions globally [3]. High-performance habitats prove that it is possible to reduce energy consumption, while providing good comfort $[4,5]$. Buildings represent a key sector of total world energy consumption, with the current energy demand in the buildings sector increasing by nearly $40 \%$ in some countries [6]. Pfafferott et al. proposed various techniques of passive cooling strategies [7]. Awareness-raising is a fundamental element in reducing emissions [8], adopting technologies that promote energy efficiency [9], and designing sustainable transportation systems
$[10,11]$. Experts proposed the building zero-energy 'concept for improving energy efficiency by reducing energy demand in buildings. Today, this concept remains a major concern for leadership worldwide. Zero energy buildings (ZEBs) have evolved over the last few years in countries that adopted an integrated energy policy. The definition of net zero-energy building concept (net ZEB) varies according to the political ambitions and specific conditions of a country. This study considers energy consumption according to intensity of use in buildings, daily mobility (transportation), as well as production of renewable energy. Several researchers have proposed various techniques to implement the concept of net zero-energy buildings (net ZEBs). Since 2002, a directive to evaluate the energy performance of buildings (Energy Performance of Buildings Directive, EPBD) was established by the European

\footnotetext{
* Corresponding author. Beneficiary of an AXA Research Fund Post-doctoral Grant, Research Leaders' Fellowships, AXA SA 25 Avenue Matignon, 75008, Paris, France.

E-mail addresses: kameni.modeste@yahoo.fr, mkameni@uliege.be (M.K. Nematchoua).
} 
Commission. In addition, in its new strategy towards sustainable development, the European Union (EU)has suggested that $100 \%$ of all new constructions must be buildings consuming almost zero energy (nearly ZEBs) from 2020 onwards [2]. This directive imposes a course of action that all member states must follow. Therefore, in many countries, urban development policies must be oriented towards efficiency of the constructed units [3].

Over the past few decades, the concept of NZEB has been deeply explored to obtain energy efficiency and sustainability in the building sector using renewable energy sources [11,12]. Globally, several researchers have agreed to work in collaboration with the U.S. Department of Energy (DOE) for proposing designs to zero-energy buildings by 2025 [13]. The term 'net zero-energy building' (nZEB) is defined based on the fact that there is balance between energy produced and energy consumed in the building during one year [14]. A large number of researchers proposed an explanation for zero-energy buildings [15,16], while others mentioned support tools for facilitating different stages of design [12] or evaluating the calculation approaches [12,14,17,18]. Zero-energy designs are created with significant energy-saving features. Most zero-energy buildings use the electrical grid for energy storage, but some are independent of the grid. In these cases, energy is directly recorded on-site through renewable energy producing technologies, while reducing the use of energy through efficient HVAC and lighting technologies $[19,20]$. The concept of zero-energy is becoming popular as the production costs of alternative energy technologies decrease, while the costs of traditional fossil fuels increase [21]. However, there are several challenges that must be overcome globally. Indeed, the concept of 'net-zero' is not easily applied to multi-storey buildings in developing countries, and photovoltaic systems are still expensive. Presently, there are only a few highly efficient buildings that reach the criteria 'net zero'. Yet, combining the advancements in construction, renewable energy systems, and academic research, creating net zero-energy buildings is becoming more feasible.

In this study, we broaden the concept of 'net zero' at the neighbourhood level because it is clear that the environmental issues of tomorrow will be resolved at the urban scale. We believe that such an approach is the logical continuation of current regulations and it is important to take the plunge. This type of large-scale analysis will help to judge the real impact of this new construction mode. To deepen the study, we pushed the reflection further. Thus, unlike other studies, we will no longer work on the scale of a single building, but focus on the neighbourhood. The aim of this research is to apply an existing approach to the study of 'zero energy' at the neighbourhood level, proposed in Ref. [22] to study the feasibility of developing zero-energy residential neighbourhoods and their potential implication on the regional building stock. This framework presents a definition and a calculation method for a 'zero-energy neighbourhood' based on a balance between annual energy consumption due to buildings renovation, daily mobility, and local production of renewable energy.

In our study, we combine this existing approach [22] with a new method based on forecast scenarios, focusing essentially on four fundamental elements: degree days assessment, heavy and light renovations of buildings, photovoltaic panels and sustainable mobility, and their influence on the energy consumption patterns of nine neighbourhoods, selected on the basis of built density and statistically representative of the regional building stock. Thus, we will not study a single improvement scenario (e.g. reducing energy consumption in buildings) as followed in many previous studies, but will consider several scenarios such as climate change, renovation of buildings, photovoltaic panels, electric vehicles, distance travelled, and their combinations.

This research has several originalities and innovative aspects:

- Application of the zero-energy concept at the neighbourhood scale, without limiting the calculation to consumption in buildings but integrating the consumption in buildings and daily mobility with renewable energy production.
- Application covering nine neighbourhoods with different characteristics, especially selected based on a statistical analysis of the entire Walloon region in Belgium to define the most representative districts of the regional building stock.

- Analysis of the current energy balance of neighbourhoods as well as prospective towards 2040, and variations according to the potential evolution of four parameters.

The study is organised as follows. Section 2 analyses recent research on the implementation of 'net zero-energy' in buildings and neighbourhoods. Section 3 presents the research methodology, including methods used to assess the urban density classes in Wallonia, calculation methodology for evaluating zero-energy neighbourhoods, and detailed improvement scenarios tested. At the end of Section 3, the proposed method is developed to test its applicability and to study the feasibility of zero-energy rehabilitation neighbourhoods. Section 4 analyses the main results and compares them with other studies. Section 5 describes important results, while mentioning the limitations and perspectives of this research.

\section{From zero-energy building to zero-energy neighbourhood}

\subsection{Net zero-energy building (NZEB)}

The U.S. National Renewable Energy Laboratory (NREL) has suggested four paths for defining net zero-energy buildings (nZEB) [23]:

- Net Zero-Site Energy: A net ZEB regularly produces as much energy as it uses during a year, when estimated at the site.

- Net Zero-Source Energy: A net source ZEB regularly produces as much energy as it uses during one year, when estimated at the source.

- Net Zero-Energy Costs: In a net-cost ZEB, the amount paid by the tenant to the person in charge of the building for the energy borrowed from the network is equal to the sum the person responsible pays to cover energy expenses for one year.

- Net Zero-Energy Emissions: A net-zero emissions building regularly produces as much emissions-free renewable energy as it uses for one year.

During the past few decades, some research studies assessed NZEB worldwide. In 2006, based on an empirical study of a zero-fossil fuel residential building in the US (Boston city), Szejnwald et al. [24] found that innovation in building design can be one of the best ways to ensure energy performance. Yi et al. [25] studied certain ecological indices, based on the performance of net zero-energy buildings (NZEB) on a worldwide scale. A rigorous text was applied, and the data were processed with high precision. The results warranted that the ZEB often uses a large amount of non-renewable energy during the early years of building design before stabilizing with new sources of green energy.

In 2014, Szalay and Zöld [26] proposed a method to reduce energy demand in residential buildings in Hungary by grouping several buildings according to their geometric shapes and age in order to better define the requirements of nearly zero-energy buildings. The results were adopted in the EU for improving energy demand. Based on a simulation study conducted in an office building in Tianjin (China) with high energy performance, Zhou et al. [27] analysed the operational performance of such type of buildings. The study revealed major obstacles and problems encountered during the implementation of 'nZEB' in China and other parts of the world. Relative information on the design of HVAC systems should normally be well disclosed to customers. Srinivasan et al. [28] developed a method to maximize the use of renewable energy for improving the energy performance of buildings. Their findings explained that REB (Renewable Energy Balance) buildings are more efficient if the building is optimized from design to life cycle. Robert and Kummert [29] studied the impact of climate change on net zero-energy 
buildings (nZEB) applying a method known as 'morphing'. The analysis of hourly data of the last 50 years and a general circulation model (GCM) made it possible to make projections on the climate of Montreal and Massena cities. The results showed that the annual change in total energy consumption is relatively small, however energy shortage compared to the net-zero goal is very significant. Chastas et al. [30] showed that in passive buildings, the embodied energy varied between $11 \%$ and $33 \%$, sometimes approaching the energy demand limits of conventional and low-energy consumption buildings.

Annunziata et al. [31] conducted a campaign by distributing several questionnaires in $27 \mathrm{EU}$ member states, with the aim of providing a strong analysis of the actual national regulatory framework. The results showed that the EU has adopted different kinds of national regulations and these discrepancies can better facilitate social insertion and ZEB. Several European countries encourage the use of renewable energies [32]. Kurnitski et al. and Pikas et al. [33,34] evaluated the optimal cost of the energy performance of buildings for nearly zero-energy buildings (nZEB). The results showed that a limited number of methods made it possible to calculate the optimal cost of energy used. A review of the influence of HVAC systems on energy demand in a building and other sustainable energy supply systems facilitating the implementation of the 'zero energy' design in buildings was given by Todorovic [35]. The results suggested that it is impossible to optimize or increase the criteria related to sustainability of buildings without resorting to a new technology. Other researches on NZEB were found in Refs. [36-39].

\subsection{Net zero-energy neighbourhood (NZEN)}

Zero-energy and zero-carbon buildings have the potential for mitigating climatic change, and the damage created by the microclimate inside and around urban and rural areas. However, studies on zeroenergy buildings (ZEBs) on a neighbourhood scale are limited in the literature, not only because of the robust reflection that is needed in such studies but also because of the different hypotheses that should always be fixed, depending on the place examined. Such as: function unit (per capita, per square meter, or per habitat); main source of renewable energy (solar panel, Wind turbine, geothermal etc.); the morphology of the neighbourhood; the space occupied per inhabitant is not the same in the countries; type of climate; building materials etc.

The methodology also differs from one research to another, so it is often difficult to compare the results obtained in various research studies due to different basic assumptions. Despite this, the main objective is the same. Generally, the main purpose is that a grid-connected dwelling produces an equal amount of energy on site or produces excess of annual energy demand while using the grid as a basis. Several governments see this strategy as an innovation for developing future neighbourhoods with the net zero-energy strategy [23].

Marique and Reiter [22] proposed to enlarge the zero-energy building concept at the neighbourhood scale, based on three parameters: annual energy consumption of buildings, annual energy consumption due to daily mobility, and production of annual renewable energy. This work was applied on both urban and rural neighbourhoods. The results showed that transportation has a significant effect on energy demand in both the environments. On the other hand, Jusela et al. [40] supported the involvement of different sources of renewable energy to reach energy-positive neighbourhoods, thereby minimizing the environmental impact. Currently, the most important aspect of energy balance of neighbourhoods with zero energy is more easily justified by electricity but, in future, new management strategies should also involve local heat exchange systems [41]. In Florida, He et al. [42] suggested a method based on the Historic Green Village, analysing this net zero-energy community (NZEC). It is important to emphasize that most of the work evaluating energy issues at the neighbourhood level are often oriented towards the photovoltaic power generation mechanism, energy supply, and potential for using solar energy and urban form [43-45].
The study by Hachem et al. [43] shows that the energy load of a neighbourhood varies according to its orientation and shape. Kennedy and Sgouridis [46] proposed hierarchical emissions categories to define the neutral or especially low-carbon urban centres. Todorovic [35] combined many energy simulation tools and applied these tools for planning zero-energy cities. The impact of urban plan on energy consumption in transportation was studied in other references [47-54] and it was found that mobility is very significant for energy consumption studies.

\section{Methodology}

This research is divided into three main parts: (a)selecting representative neighbourhoods of a regional building stock to a statistical classification, (b) current average energy assessment for these nine types of neighbourhoods using national energy reports to calculate their energy consumption, and (c) study of scenarios from a 2040 prospective on the nine selected regional neighbourhoods.

\subsection{Studied region}

Belgium, a federal state, comprises three regions: Walloon Region (Wallonia), Flemish Region (Flanders), and Brussels Region (BrusselsCapital). Nearly $10.5 \%$ of the national population is concentrated in the Brussels-Capital Region, which occupies a small part of the territory $\left(161 \mathrm{~km}^{2}\right)$ that is equivalent to $0.5 \%$ of the area of Belgium. Wallonia ( $31.9 \%$ of the national population) and Flanders (57.6\% of the national population) are territories comprising small and medium-sized towns surrounded by suburban and rural areas.

\subsection{Methods used to assess urban density classes in wallonia}

Wallonia occupies the southern part of Belgium and is composed of 5 provinces, 20 boroughs, 262 municipalities, and 9876 statistical sectors. The net density classes of housing are assessed at a statistical sector level where the built net density is established. The built net density is housing net density per urbanized hectare. In fact, it is the number of dwellings per urbanized hectare in a statistical sector (SS). The SS is a neighbourhood in urban areas or a village in rural areas with more than 150 residents. In this research, we did not consider roads, collective areas, public green spaces and forests, but only building plots were considered. In addition, we considered only residential buildings.

The data used are a Belgian cadastral matrix. First, we cut the matrix to only consider the Wallonia Region using spatial join tool with the Wallonia statistical sectors shape file. Wallonia is composed of $6,629,332$ buildings (residential, tertiary, and industrial). We removed tertiary and industrial buildings, all buildings with shape area less than $15 \mathrm{~m}^{2}$, and only considered closed buildings. The residential buildings used in our study are $1,470,378$ and are composed of six types of buildings: 462,025 terraced houses, 434,148 semi-detached houses, 542,652 detached houses, 29,926 apartment buildings, 1495 detached castles, and 132 semi-detached castles. For calculating the number of dwellings in each apartment building, we considered the average area of an apartment in Wallonia to be $66.84 \mathrm{~m}^{2}$ [55]. We calculated the total shape area of the 29,926 apartment buildings and divided it by the average shape area per apartment and found 96,933 apartments in Wallonia. In total, we used 1,537,385 dwellings in Wallonia to assess the urban density classes of this region.

This results in classes of net density assessed by type of buildings in each of the 9876 statistical sectors. The detailed methodology is presented below. Using R software, the first step consists of separating the different types of buildings. The library 'plyr' is installed and in the matrix we separated the terraced, semi-detached. And detached houses. For this, we checked in the matrix the nature = 'MAISON' and 'HAUS' and, at the same time, the type of construction in the matrix is ' $A$ ', ' $B$ ', and ' $C$ '. A represents terraced houses, $B$ stands for semi-detached houses, 
Table 1

Classes and densities of neighbourhoods.

\begin{tabular}{|c|c|c|c|}
\hline Class & $\begin{array}{l}\text { Housing Net Density } \\
\text { (number of dwellings } \\
\text { per ha) }\end{array}$ & Neighbourhood type & Housing type \\
\hline 1 & $0-4.9$ & Rural (Rural isolated) & Individual \\
\hline 2 & $5-8.9$ & Rural (rural in ribbon) & Individual \\
\hline 3 & 9-13.9 & Rural (village periphery) & Individual \\
\hline 4 & $14-20.9$ & $\begin{array}{l}\text { Peri-urban allotment or small } \\
\text { villages }\end{array}$ & Mixed \\
\hline 5 & $21-31.9$ & $\begin{array}{l}\text { Peri-urban allotment or large } \\
\text { villages }\end{array}$ & Mixed \\
\hline 6 & $32-48.9$ & $\begin{array}{l}\text { Suburban allotment or centre of } \\
\text { large villages }\end{array}$ & Mixed \\
\hline 7 & 49-78.9 & $\begin{array}{l}\text { Suburban allotment on the city } \\
\text { periphery or urban semi- } \\
\text { continuous }\end{array}$ & Mixed \\
\hline 8 & 79-137.9 & Urban (urban blocks in the city) & $\begin{array}{l}\text { Collective } \\
\text { low }\end{array}$ \\
\hline 9 & $138-255.9$ & $\begin{array}{l}\text { Urban continuous (dense urban } \\
\text { blocks downtown) }\end{array}$ & $\begin{array}{l}\text { Collective } \\
\text { Medium }\end{array}$ \\
\hline
\end{tabular}

Table 2

Number of dwellings in Wallonia found in each category of neighbourhood.

\begin{tabular}{llllll}
\hline Class & $\begin{array}{l}\text { Net Density } \\
\text { (ND) }\end{array}$ & $\begin{array}{l}\text { Terraced } \\
\text { houses }\end{array}$ & $\begin{array}{l}\text { Semi- } \\
\text { detached } \\
\text { houses }\end{array}$ & $\begin{array}{l}\text { Detached } \\
\text { houses }\end{array}$ & Apartments \\
\hline 1 & $0-4.9$ & 26 & 139 & 803 & 14 \\
2 & $5-8.9$ & 73 & 362 & 1637 & 40 \\
3 & 9 à 13.9 & 208 & 681 & 3365 & 110 \\
4 & $14-20.9$ & 418 & 1598 & 6576 & 230 \\
5 & $21-31.9$ & 1174 & 3692 & 13,984 & 396 \\
6 & $32-48.9$ & 2282 & 7110 & 24,254 & 731 \\
7 & $49-78.9$ & 12,845 & 35,025 & 111,919 & 3541 \\
8 & $79-137.9$ & 294,576 & 311,005 & 367,239 & 64,260 \\
9 & $138-255.9$ & 150,423 & 74,668 & 14,370 & 27,611 \\
Totals & & 462,025 & 434,280 & 544,147 & 96,933 \\
Total & & $1,537,385$ & & & \\
\hline
\end{tabular}

and $\mathrm{C}$ for detached houses. Next, we also separated castles with nature $=$ 'CHATEAU' and 'SCHLOSS' and construction type is ' $\mathrm{B}$ ' and ' $\mathrm{C}$ '. Following this, we separated the apartment buildings where we used the 'set diff' function in $\mathrm{R}$ to consider the remaining buildings of the matrix as apartment buildings. Next, we calculated the number of single apartments considering the total shape area of apartment buildings divided by the average shape area of an apartment in Wallonia. In addition, at the same time, we considered the statistical sector and municipality where it is located because there are some statistical sectors with the same name but in different municipalities.

Subsequently, using the 'group by' function, we calculated the number of each type of dwellings in a statistical sector (SS) and in a municipality at the same time. Next, using the 'reduce' and 'merge' functions we sorted the total number of each building by building type in an SS and the same for the total shape area. The next step focused on converting the shape area into hectares because it was given in $\mathrm{m}^{2}$ in the cadastral matrix. Then, we calculated the net urban density per SS and per municipality. Lastly, we calculated the urban density classes and found that Wallonia is composed of nine density classes. The distribution of the statistical sectors according to the net density of dwellings per hectare in Wallonia is expressed in the form of a Gaussian curve. The urban density classes were assessed using Jenks' natural breaks classification and the SOLEN method [56,57].

Nine density classes were used to classify the 9876 Walloon SS according to their net density of dwellings. The housing net density and the typology of these neighbourhoods are presented in Table 1.

Table 2 gives the number of dwellings found for each type of neighbourhood, representative of the Walloon building stock. The numbers of castles is low compared to other building types, so we

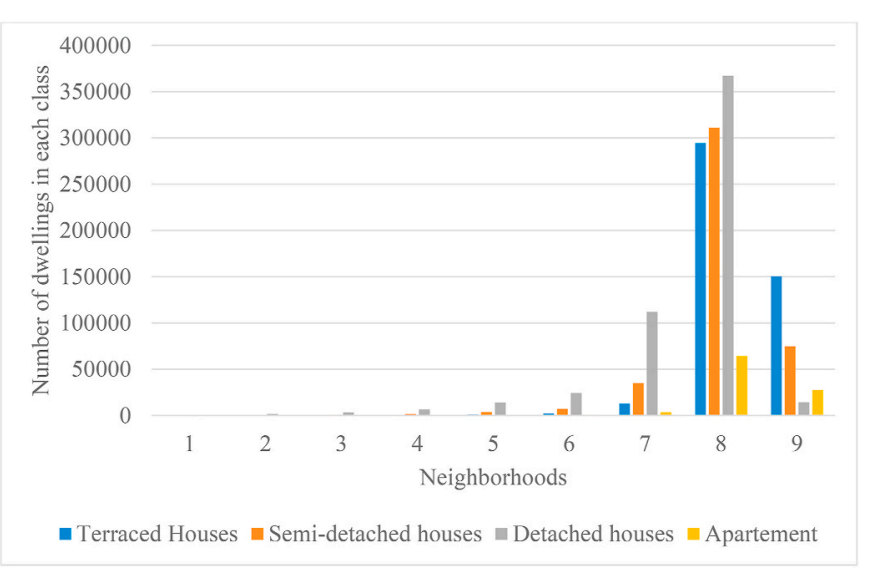

Fig. 1. Number of dwellings in Wallonia in each neighbourhood category.

combined the semi-detached castles with semi-detached houses and detached castles with detached houses in Table 2.

The detached houses are dominant (more than $68 \%$ of dwellings) while number of apartments is negligible (less than 3\%) in almost all classes except the last two classes, that is, neighbourhoods 8 and 9. In neighbourhood class 9 , terraced houses are dominant; the neighbourhood class 9 includes $56.3 \%$ of terraced houses, $28 \%$ of semi-detached houses, $10.3 \%$ of apartments, and only $5.4 \%$ of detached houses. In neighbourhood class 8 , the housing distribution includes $28.4 \%$ of terraced houses, $30 \%$ of semi-detached houses, $35.4 \%$ of detached houses, and $6.2 \%$ of apartments. All the details are represented in Fig. 1.

After using R software, the data are stored in a csv single file and are joined with the SS shape files for cartography. The assessed housing net density classes are spatialized using Quantum GIS (QGIS) software. Big cities such as Liege, Namur, Charleroi are mostly dominated by class 8 followed by class 9 and class 7, as shown in Fig. 2 .

\subsection{Energy consumption in the Walloon Region}

The factors affecting energy consumption in this region are:(i) climatic conditions, a key factor in household consumption, as a large part of household consumption is devoted to heating in Wallonia; (ii) disposable income per household: according to a household budget survey, the average real income per household in Wallonia was 7\% lower than the Belgian average in 2012; (iii) price of energy: any rise in energy costs could affect energy demand in the neighbourhoods; (iv) energy performance of the existing housing stock; and (v) housing facilities.

Distribution of energy consumption according to building categories is presented in Table 3.

\subsection{Applied scenarios in the neighbourhoods}

In this study, four scenarios have been retained for mitigating energy consumption in 1,537,385 dwellings studied in Wallonia: (i) scenario 1, linked to variations in climate change in the number of degree days; (ii) scenario 2, linked to heavy and light renovation of buildings; (iii) scenario 3, linked to photovoltaic panels; and (iv) scenario 4, linked to mobility, with an increase in electric vehicles or a decrease in distance travelled.

\section{Results}

\subsection{Application of degree-days scenario}

The first scenario set up shows the variation in consumption as a function of the number of degree days recorded in a year. These 


\section{Urban density classes per statistical sector (SS) in Wallonia, Belgium}

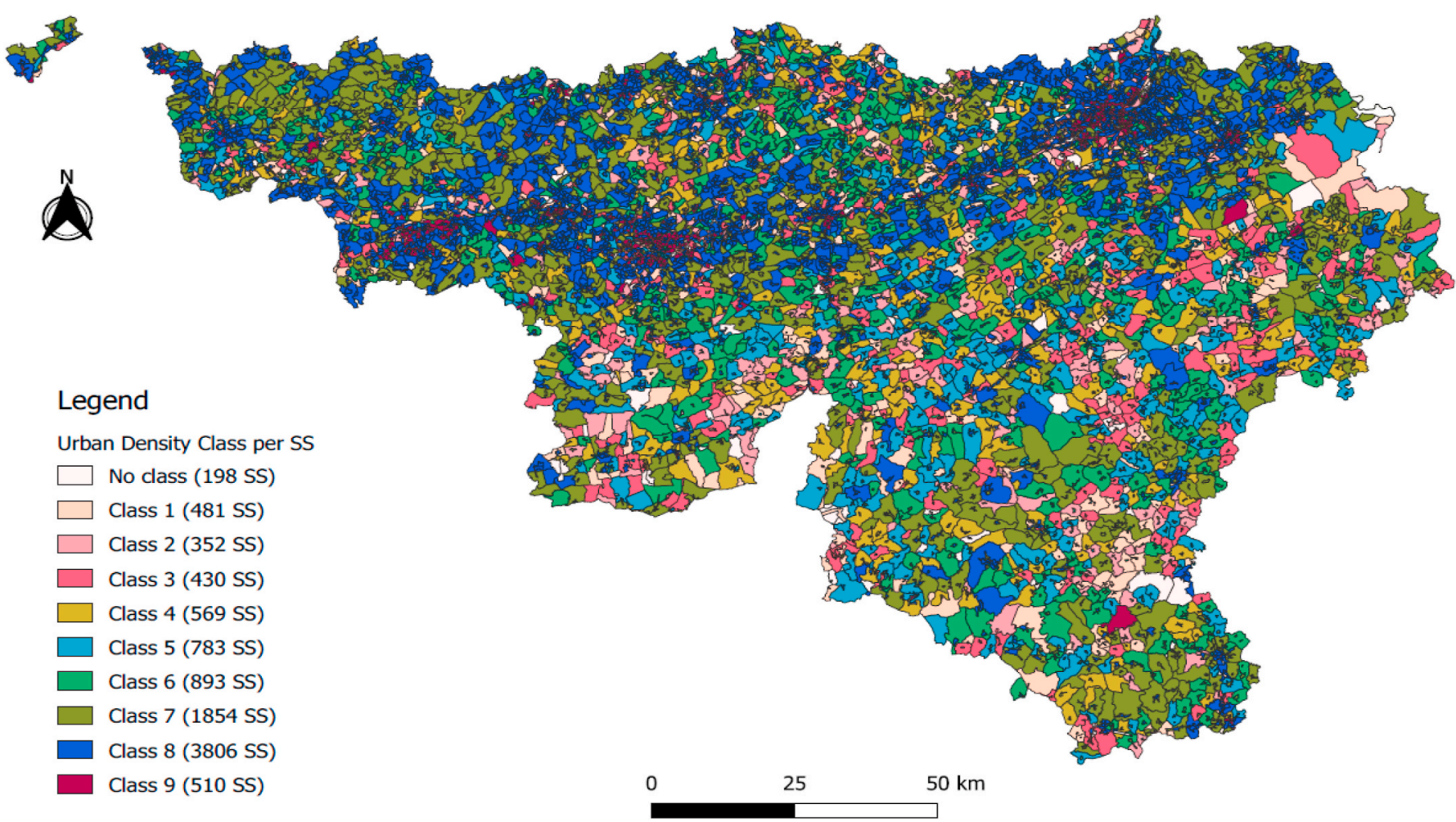

Fig. 2. Distribution of different density classes of housing in Wallonia, Belgium.

Table 3

Energy consumption of each housing category [58].

\begin{tabular}{llll}
\hline $\begin{array}{l}\text { Housing } \\
\text { type }\end{array}$ & $\begin{array}{l}\text { Average } \\
\text { living area } \\
{\left[\mathrm{m}^{2}\right]}\end{array}$ & $\begin{array}{l}\text { Heating } \\
\text { consumption per } \\
\text { square meter in } \\
\mathrm{kWh} / \mathrm{m}^{2}\end{array}$ & $\begin{array}{l}\text { Total annual energy } \\
\text { consumption per dwelling } \\
\text { (heating + electricity) in } \\
\mathrm{kWh} / \text { year }\end{array}$ \\
\hline $\begin{array}{l}\text { Apartment } \\
\begin{array}{l}\text { Terraced } \\
\text { House }\end{array}\end{array}$ & 60.3 & 182.28 & $15,444.61$ \\
$\begin{array}{c}\text { Semi- } \\
\text { detached } \\
\text { house }\end{array}$ & 87.4 & 230.61 & $22,982.28$ \\
$\begin{array}{c}\text { Detached } \\
\text { house }\end{array}$ & 97.7 & 239.72 & $25,581.37$ \\
\hline
\end{tabular}

represent the sum over the year for the differences between the average indoor temperatures during the heating period and the average daily outdoor temperatures. The indoor comfort temperature is $18^{\circ} \mathrm{C}$ and solar gains are recorded at $3{ }^{\circ} \mathrm{C}$ and deducted from the internal temperature. Therefore, degree days are determined by the difference between $15{ }^{\circ} \mathrm{C}$ and the daily outdoor temperature throughout the year.

Degree days are important for calculating the evolution of heat needs since they represent the climate, and this last one has a significant impact on buildings energy consumption. We also point out that only
$70 \%$ of heat needs vary in proportion to changes in the number of degree days, while the remainder $30 \%$ of consumption is assumed to be invariable considering the thermal inertia of buildings [58]. The prospective data were carried out using a linear regression based on the evaluation of degree days observed since the 1960s in Belgium [59]. We used 2012 as the reference year, which is embodied in a normal climatic year with $1914.7^{\circ}$ days, and we observed the evolution of energy consumption for three periods (2020, 2030, and 2040) depending on the evolution of degree days. The results obtained after applying this scenario are illustrated in Table 4.

Energy consumption is the highest in neighbourhood class 8, because this neighbourhood category has the highest number of dwellings in the region. After analysing the results in Table 4, it is found that application of the degree-days scenario will allow an average reduction in energy consumption of $9.1 \%$ in 2040 (compared to 2012) in the residential building stock in Wallonia, which would be similar in the majority of countries having the same type of climate as Belgium (temperate).

\subsection{Application of renovation scenarios}

The second scenario consists of the realization of light and heavy renovations within buildings. By analysing the current trends in the Walloon housing stock and other countries, we obtained the following frequency as given in Ref. [60]: (i) annual light renovation rate of $0.8 \%$,

Table 4

Variation in energy consumption in the Walloon building stock, based on type of neighbourhood, after applying the degree-days scenario.

\begin{tabular}{|c|c|c|c|c|c|c|c|c|c|c|}
\hline & \multirow[t]{2}{*}{ Degree days } & \multicolumn{9}{|c|}{ Types of neighbourhoods in the Walloon building stock in Belgium } \\
\hline & & 1 & 2 & 3 & 4 & 5 & 6 & 7 & 8 & 9 \\
\hline Consumption in 2012 (GWh) & 1914.7 & 24.351 & 52.289 & 107.632 & 217.669 & 475.511 & 849.137 & 4030.789 & $24,857.00$ & 6151.187 \\
\hline Consumpti $\mathrm{n}$ in 2020 (GWh) & 1832.7 & 23.725 & 50.945 & 104.867 & 211.077 & 461.296 & 824.324 & 3910.246 & $24,111.822$ & 5967.175 \\
\hline Consumption in 2030 (GWh) & 1730.3 & 22.709 & 48.763 & 100.375 & 202.994 & 443.454 & 791.892 & 3759.0523 & $23,181.258$ & 5736.503 \\
\hline Consumption in 2040 (GWh) & 1627.8 & 19.836 & 42.596 & 87.680 & 194.838 & 425.635 & 760.072 & 3450.47 & $21,278.31$ & 5598.140 \\
\hline
\end{tabular}


Table 5

Variation in energy consumption in the Walloon building stock, by neighbourhood class, after applying renovation scenarios.

\begin{tabular}{|c|c|c|c|c|c|c|c|c|c|c|}
\hline \multirow[t]{3}{*}{ Energy consumption (Gwh/year) } & \multirow{3}{*}{$\begin{array}{l}\text { year } \\
\overline{2012}\end{array}$} & \multicolumn{9}{|c|}{ Types of neighbourhoods in the Walloon building stock in Belgium } \\
\hline & & \multirow{2}{*}{$\frac{1}{24.351}$} & \multirow{2}{*}{$\frac{2}{52.289}$} & \multirow{2}{*}{$\frac{3}{107.632}$} & \multirow{2}{*}{$\frac{4}{217.669}$} & \multirow{2}{*}{$\frac{5}{475.511}$} & \multirow{2}{*}{$\frac{6}{849.137}$} & \multirow{2}{*}{$\frac{7}{4030.789}$} & \multirow{2}{*}{$\frac{8}{24,857.00}$} & \multirow{2}{*}{$\frac{9}{6151.187}$} \\
\hline & & & & & & & & & & \\
\hline \multirow[t]{3}{*}{ After Light renovation (0.8\%/year) } & 2020 & 23.68 & 50.83 & 104.66 & 211.67 & 462.39 & 825.70 & 3919.48 & $24,166.66$ & 5979.46 \\
\hline & 2030 & 22.90 & 49.15 & 101.21 & 204.68 & 447.13 & 798.44 & 3790.04 & $23,363.83$ & 5779.74 \\
\hline & 2040 & 22.25 & 47.76 & 98.33 & 198.86 & 434.41 & 775.71 & 3682.11 & $22,694.41$ & 5613.21 \\
\hline \multirow[t]{3}{*}{ After Heavy renovation $(0.5 \%$ /year) } & 2020 & 23.50 & 50.47 & 103.88 & 210.09 & 458.94 & 819.53 & 3890.19 & $23,984.99$ & 5934.26 \\
\hline & 2030 & 22.49 & 48.29 & 99.41 & 201.02 & 439.13 & 784.15 & 3722.19 & $22,943.03$ & 5675.06 \\
\hline & 2040 & 21.67 & 46.46 & 95.57 & 193.19 & 421.94 & 753.39 & 3575.88 & $22,035.92$ & 5449.60 \\
\hline \multirow[t]{3}{*}{ After Heavy and Light renovation (same rate/year) } & 2020 & 22.87 & 49.10 & 101.07 & 204.40 & 446.50 & 806.32 & 3784.67 & $23,330.53$ & 5771.46 \\
\hline & 2030 & 21.22 & 45.56 & 93.78 & 189.64 & 414.25 & 747.61 & 3511.13 & 21,634 & 5349.41 \\
\hline & 2040 & 19.91 & 42.74 & 87.98 & 177.92 & 388.63 & 700.96 & 3293.75 & $20,285.78$ & 5014.02 \\
\hline \multirow[t]{3}{*}{ After Heavy and Light renovation $x 2$} & 2020 & 21.51 & 46.20 & 95.09 & 192.29 & 420.04 & 758.15 & 3560.23 & $21,938.50$ & 5425.16 \\
\hline & 2030 & 18.72 & 40.18 & 82.71 & 167.24 & 365.29 & 658.45 & 3095.70 & $19,057.44$ & 4708.45 \\
\hline & 2040 & 16.75 & 35.97 & 74.03 & 149.69 & 326.94 & 588.63 & 2770.38 & $17,039.70$ & 4206.51 \\
\hline Heavy renovation $100 \%$ & 2040 & 2.79 & 5.97 & 12.29 & 24.75 & 53.88 & 95.90 & 453.90 & 2672.49 & 632.42 \\
\hline Light renovation $100 \%$ & 2040 & 13.57 & 29.13 & 59.96 & 121.21 & 264.69 & 472.52 & 2242.34 & $13,764.75$ & 3391.81 \\
\hline
\end{tabular}

and (ii) annual heavy renovation rate of $0.5 \%$. It is important to note that light renovations include roof renovation, new window frames, a thermostat, and a more efficient heating system. Heavy renovations refer to the total energy renovation of the entire building (i.e. walls, roof, windows, and systems). In this study, we applied the renovation rate to all the dwellings distributed in the different neighbourhoods that we studied. We estimated that a major renovation allows the renovated building to meet the 'low energy' criterion, with heating energy consumption of $30 \mathrm{kWh} / \mathrm{m}^{2} /$ year [57]. A light renovation leads the building to a consumption half-way between that of the 'low energy' criterion and that currently observed. However, until then we had consumption by the type of housing and now we have consumption per $\mathrm{m}^{2}$ depending on the type of housing. We, therefore, determined the average surface area of each dwelling, number of $\mathrm{m}^{2}$ contained in each typical neighbourhood class, and estimated energy consumption after the renovations. The results of this scenario are shown on Table 5. We calculated energy consumption following six sub-scenarios until 2040:

- Light renovation of $0.8 \%$ of the building stock per year,

- Heavy renovation of $0.5 \%$ of the building stock per year,

- Light renovation (rate $=0.8 \%$ per year) + Heavy renovation (rate $=$ $0.5 \%$ per year),

- Doubling the renovation rate per year $(1.6 \%$ for light renovation + $1 \%$ for heavy renovation),

- Heavy renovation applied on the entire building stock of the region, and

- Light renovation applied on the entire building stock of the region.

After analysing Table 4 results, application of the current renovation rate in Wallonia will allow an average reduction in energy consumption of $18.19 \%$ in 2040 (heavy- and light-renovation scenario) compared to 2012, while doubling this current renovation rate will allow to reach a reduction of $31.23 \%$ (heavy- and light-renovation scenario $\mathrm{x} 2$ ), and renovating the entire building stock will generate energy consumption reduction of $88.82 \%$ with $100 \%$ of heavy renovation and energy consumption reduction of $44.41 \%$ with $100 \%$ light renovation. These conclusions should be similar in various European countries having the same type of old building stock as Belgium. Among the different types of renovation scenarios, $100 \%$ heavy renovation seems to be the best compared to the other five scenarios and it is most promising for reaching nearly zero-energy residential neighbourhoods. If it seems unlikely that this level of renovation can be achieved for the entire regional stock by 2040 , it is a strategy to be favoured in small scale projects (such as renovation of neighbourhoods).

\subsection{Application of photovoltaic panel scenario}

Photovoltaic solar energy is electricity produced by transforming part of the solar radiation using a photovoltaic cell. Using solar energy to lower the amount of non-renewable energy consumption seems to be an effective alternative. The potential of urban and rural neighbourhoods used in this research for assessing solar photovoltaic electricity production are derived from simulations using the Town Scope tool [61]. Globally, in this study photovoltaic panels were fitted on building roof tops. Indeed, they are less productive on facades in Belgium. For this scenario, we considered photovoltaic panels installed on $20 \mathrm{~m}^{2}$ area of buildings. According to the literature, it is concluded that these panel arrays for domestic use of $3 \mathrm{~kW}$ produce $3000 \mathrm{kWh} /$ year.

By applying this scenario to our neighbourhoods, we obtain a consumption reduction in fossil fuels of more than $4612 \mathrm{GWh} /$ year. This scenario needs to be nuanced by considering a roof correction factor [56, 57], taking into account the impact of shading between buildings, according to the type of neighbourhood built density. Roof correction factor was assessed and is shown in Table 6. With this correction factor, we obtain new production for solar energy slightly lower than earlier. Finally, the total energy generation potential of photovoltaic panels on the rooftops of all residential buildings in Wallonia amounts to $3404 \mathrm{GWh}$ /year, which corresponds to $9.26 \%$ of total energy consumption of the regional residential building stock for the reference year (2012).

Table 6

Variation in energy consumption in the Walloon building stock, by neighbourhood class, after applying the photovoltaic panel scenario.

\begin{tabular}{|c|c|c|c|c|c|c|c|c|c|c|}
\hline & \multicolumn{10}{|c|}{ Types of neighbourhoods in the Walloon building stock in Belgium. } \\
\hline & 1 & 2 & 3 & 4 & 5 & 6 & 7 & 8 & 9 & Total \\
\hline Energy consumption in 2012 (GWh/year) & 24.35 & 52.29 & 107.63 & 217.67 & 475.51 & 849.14 & 4030.79 & $24,857.00$ & 6151.19 & $36,765.57$ \\
\hline Solar energy production (GWh/year) & 2.95 & 6.34 & 13.09 & 26.47 & 57.74 & 103.13 & 489.99 & 3111.24 & 801.22 & 4612.16 \\
\hline Fossil energy consumption (GWh/year) & 21.41 & 45.95 & 94.54 & 191.20 & 417.77 & 746.01 & 3540.80 & $21,745.76$ & 5349.97 & $32,153.41$ \\
\hline Roof correction factor (RF) & 1 & 0.98 & 0.98 & 0.96 & 0.96 & 0.95 & 0.82 & 0.72 & 0.7 & - \\
\hline Solar energy production with Correction factor (RF) & 2.95 & 6.21 & 12.83 & 25.41 & 55.43 & 97.97 & 401.79 & 2240.09 & 560.85 & 3403.55 \\
\hline Fossil energy consumption with correction factor (RF) & 21.40 & 46.08 & 94.80 & 192.26 & 420.08 & 751.16 & 3629.00 & $22,616.91$ & 5590.33 & $33,362.02$ \\
\hline
\end{tabular}


Table 7

Variation in energy consumption in the Walloon building stock, by neighbourhood class, after applying the mobility scenarios.

\begin{tabular}{|c|c|c|c|c|c|c|c|c|c|c|}
\hline & \multicolumn{10}{|c|}{ Types of neighbourhoods in the Walloon building stock in Belgium. } \\
\hline & 1 & 2 & 3 & 4 & 5 & 6 & 7 & 8 & 9 & Total \\
\hline Energy consumption due to mobility of residents (Gwh) & 9.78 & 21.02 & 43.43 & 87.82 & 191.58 & 342.21 & 1354.18 & 8598.53 & 2214.32 & $12,862.87$ \\
\hline Energy consumption assuming half of electric cars (Gwh) & 6.52 & 14.03 & 28.99 & 58.61 & 127.85 & 228.38 & 903.75 & 5738.48 & 1477.79 & 8584.41 \\
\hline Energy consumption assuming all cars are electric (Gwh) & 3.40 & 7.31 & 15.11 & 30.55 & 66.65 & 119.06 & 471.13 & 2991.48 & 770.38 & 4475.07 \\
\hline Energy consumption with reduced distances $(-20 \%)$ & 8.14 & 17.51 & 36.17 & 73.14 & 159.56 & 285.02 & 1083.92 & 6882.51 & 1772.41 & $10,318.4$ \\
\hline
\end{tabular}

Some detailed results are shown for each type of neighbourhood in Table 6:

- Energy consumption of all buildings for the reference year,

- Solar energy production from $20 \mathrm{~m}^{2}$ of PV panels on all the building rooftops (without considering the effects of shading between buildings),

- Remaining fossil energy consumption after the use of solar energy produced (without considering the impact of shading between buildings),

- Roof correction factor to apply on solar energy production taking into account the impact of shading between buildings, based on their built density [56,57].

- Solar energy production with roof correction factor, considering the impact of shading between buildings, based on their built density $[56,57]$.

- Remaining fossil energy consumption after using the solar energy produced, considering the impact of shading between buildings, based on the built density $[56,57]$.

The application of the photovoltaic scenario will allow an average reduction in non-renewable energy consumption of $9.26 \%$ for the Walloon residential building stock. This finding depends on several factors such as climate, orientation of PV, shading effect, sunshine, etc.

This result shows that the yield of photovoltaic panels is low in temperate zones compared to tropical zones.

\subsection{Application of mobility scenario}

Transportation is a major consumer of energy because commuting is necessary to travel from home to places of work or study and return back. Given this fact, in this research, we evaluate energy consumption related to current household travel and by 2040. Data adopted for assessing annual energy use regarding daily mobility could be registered from different kinds of sources, such as 'in situ' campaigns, national censuses among others. The Beldam survey was carried out between December 2009 and January 2011 for 8532 households, including 15,821 people aged 6 years and above [62]. The annual energy consumption for daily mobility was evaluated with some indicators such as those shown in Ref. [53,63]. The distances travelled by Walloons are, on average, longer than those made by the inhabitants of Brussels city. The proximity (or not) of amenities around the dwellings is a factor that may explain these differences.

The daily work-related trips are, on average, quite long and measure around $22 \mathrm{~km}$. However, this is perfectly consistent with the distances between the home and work place already evaluated through other surveys. For more 'recreational' activities (i.e. visits to friends, family, sports, recreation, and culture), the average distance of a round trip is $13.4 \mathrm{~km}$. The results of the BELDAM survey [62] also affirmed that schools, shops, and services are closer to dwellings than work places, with round trips of $18 \mathrm{~km}$ to get to schools, $14 \mathrm{~km}$ to go shopping, and $13 \mathrm{~km}$ for other services.

It is, therefore, necessary to determine the average distance travelled by a resident considering the different modes of transport and the corresponding kilometric fluctuations within each of them. Thus, from the Beldam report we obtained the average distance depending on the type of transport and average number of trips per resident per day. Combining these data, we obtained the average kilometres travelled by a single resident per day and annually, which led to an average distance travelled of $30 \mathrm{~km}$ per day and an average annual distance of $10,950.00 \mathrm{~km}$. However, it seemed necessary to distinguish the more rural districts where the distances travelled are slightly higher [53] due to the low density of buildings and services, by applying a factor of $+20 \%$, which led to an average distance travelled of $36 \mathrm{~km}$ per day and an average annual distance of $13,140.00 \mathrm{~km}$.

The average consumption for different transportation types in Wallonia [53] is $0.56 \mathrm{kWh} / \mathrm{km}$ for diesel vehicles, $0.61 \mathrm{kWh} / \mathrm{km}$ for gasoil vehicles, $0.585 \mathrm{kWh} / \mathrm{km}$ for an average motor vehicle, $0.45 \mathrm{kWh} / \mathrm{km}$ for a bus, $0.15 \mathrm{kWh} / \mathrm{km}$ for a train, and $0 \mathrm{kWh} / \mathrm{km}$ for non-motorized modes of transport. Next, to calculate the annual transport consumption for a resident we established the average consumption per kilometre (travelled in Wallonia), which is $0.32 \mathrm{kWh} / \mathrm{km}$.

After determining energy consumption for travel, we implemented reduction scenarios based on certain assumptions:

(i) Now, a car park is not composed solely of cars running on fuel but some of them are electric. The first scenario assumes that half the cars will be electric by 2040 and the second scenario that the entire car park will comprise electric vehicles in 2040. To achieve this, we first determined the annual consumption of a resident living in urban areas versus a resident living in rural areas. We adopted the same method described above, by assuming that an electric car consumes $0.17 \mathrm{kWh} / \mathrm{km}[62,69]$. The average consumption was $0.21 \mathrm{kWh} / \mathrm{km}$ for a half electric car park and average consumption of $0.11 \mathrm{kWh} / \mathrm{km}$ by using only electric cars.

(ii) Now we will opt for a hypothesis impacting the number of kilometres. We consider that the distance travelled by a resident will be reduced by $20 \%$ by 2040 , if residents live closer to their place of work and their children's school. This translates into $24 \mathrm{~km}$ per day travelled for urban and suburban residents and $30 \mathrm{~km}$ for those living in rural areas. The results obtained are as follows: average consumption $(0.32 \mathrm{kWh} / \mathrm{km}$, both); distance travelled in one year $(8760.00 \mathrm{~km}$ per resident in urban areas and $10,950.00 \mathrm{~km}$ per resident in rural areas). Similarly, we have determined future consumption and the results are shown Table 7.

The application of the transportation scenario will allow an average reduction in mobility energy consumption in 2040 of $65.21 \%$ with $100 \%$ of electric cars, $33.26 \%$ with $50 \%$ of electric cars, and $16.78 \%$ to reduced-distances scenario, based on the total building stock in Wallonia. This conclusion should be similar in most countries having the same type of transport systems than Belgium, mainly based on motor vehicles.

\subsection{Summary of scenarios by neighbourhood class}

Once all the scenarios were applied, we performed a synthesis of the latter by neighbourhood class, so as to compare them and to identify the most effective scenarios by 2040 . The results are shown in Table 8.

The average reduction in energy consumption for residential buildings in Wallonia (Belgium) in 2040 (compared to 2012) will reach $9.10 \%$ due to evolution in degree days, $18.19 \%$ to the current annual 
Table 8

Summary of energy consumption in each neighbourhood class in 2040 (by scenario).

\begin{tabular}{|c|c|c|c|c|c|c|c|c|c|}
\hline & \multicolumn{9}{|c|}{ Types of neighbourhoods in the Walloon building stock in Belgium. } \\
\hline & 1 & 2 & 3 & 4 & 5 & 6 & 7 & 8 & 9 \\
\hline Initial buildings energy consumption (Gwh) & 24.351 & 52.289 & 107.632 & 217.669 & 475.511 & 849.137 & 4030.789 & $24,857.000$ & 6151.187 \\
\hline $\begin{array}{l}\text { Building energy consumption in } 2040 \text { with variation in degree days } \\
\text { (Gwh) }\end{array}$ & 19.836 & 42.596 & 87.680 & 194.838 & 425.635 & 760.072 & 3450.47 & $21,278.31$ & 5598.140 \\
\hline $\begin{array}{l}\text { Building energy consumption with current renovation rate: Heavy } \\
\text { and light renovations (Gwh) }\end{array}$ & 19.91 & 42.74 & 87.98 & 177.92 & 388.63 & 700.96 & 3293.75 & $20,285.78$ & 5014.02 \\
\hline $\begin{array}{l}\text { Building energy consumption while doubling the renovation rate } \\
\text { (heavy }+ \text { light renovation } \mathrm{x} 2 \text { ) (Gwh) }\end{array}$ & 16.75 & 35.97 & 74.03 & 149.69 & 326.94 & 588.63 & 2770.38 & $17,039.70$ & 4206.51 \\
\hline $\begin{array}{l}\text { Fossil energy consumption due to buildings with photovoltaic } \\
\text { panels (Gwh) }\end{array}$ & 21.40 & 46.08 & 94.80 & 192.26 & 420.08 & 751.16 & 3629.00 & $22,616.91$ & 5590.33 \\
\hline Initial transportation energy consumption (Gwh) & 9.78 & 21.02 & 43.43 & 87.82 & 191.58 & 342.21 & 1354.18 & 8598.53 & 2214.32 \\
\hline $\begin{array}{l}\text { Transportation energy consumption assuming all cars are electric } \\
\text { (Gwh) }\end{array}$ & 3.40 & 7.31 & 15.11 & 30.55 & 66.65 & 119.06 & 471.13 & 2991.48 & 770.38 \\
\hline $\begin{array}{l}\text { Transportation energy consumption assuming a } 20 \% \text { reduction in } \\
\text { distances travelled (Gwh) }\end{array}$ & 8.14 & 17.51 & 36.17 & 73.14 & 159.56 & 285.02 & 1083.92 & 6882.51 & 1772.41 \\
\hline
\end{tabular}

Table 9

Percentage reduction of energy consumption in each neighbourhood class in 2040 (by scenario).

\begin{tabular}{|c|c|c|c|c|c|c|c|c|c|}
\hline & \multicolumn{9}{|c|}{ Types of neighbourhoods in the Walloon building stock in Belgium. } \\
\hline & 1 & 2 & 3 & 4 & 5 & 6 & 7 & 8 & 9 \\
\hline \multicolumn{10}{|c|}{ Rate of energy consumption reduction in the residential buildings by 2040 (compared to 2012) } \\
\hline Variation in degree-days & $8.99 \%$ & $8.99 \%$ & $9.29 \%$ & $8.99 \%$ & $8.99 \%$ & $8.95 \%$ & $8.56 \%$ & $8.56 \%$ & $9.10 \%$ \\
\hline Heavy and light renovations with current renovation rate & $18.23 \%$ & $18.26 \%$ & $18.26 \%$ & $18.26 \%$ & $18.27 \%$ & $17.45 \%$ & $18.28 \%$ & $18.39 \%$ & $18.48 \%$ \\
\hline Heavy and light renovations while doubling the current renovation rate & $31.21 \%$ & $31.21 \%$ & $31.22 \%$ & $31.23 \%$ & $31.24 \%$ & $30.67 \%$ & $31.27 \%$ & $31.45 \%$ & $31.61 \%$ \\
\hline Heavy renovation $(100 \%)$ & $88.54 \%$ & $88.58 \%$ & $88.58 \%$ & $88.63 \%$ & $88.67 \%$ & $88.71 \%$ & $88.74 \%$ & $89.25 \%$ & $89.72 \%$ \\
\hline Light renovation $(100 \%)$ & $44.27 \%$ & $44.29 \%$ & $44.29 \%$ & $44.31 \%$ & $44.33 \%$ & $44.35 \%$ & $44.37 \%$ & $44.62 \%$ & $44.86 \%$ \\
\hline Photovoltaic panels & $9.25 \%$ & $9.26 \%$ & $9.30 \%$ & $9.25 \%$ & $9.24 \%$ & $9.30 \%$ & $9.25 \%$ & $9.26 \%$ & $9.26 \%$ \\
\hline \multicolumn{10}{|c|}{ Rate of energy consumption reduction in the mobility sector by 2040} \\
\hline $100 \%$ electric cars & $65.23 \%$ & $65.22 \%$ & $64.47 \%$ & $65.5 \%$ & $65.21 \%$ & $65.20 \%$ & $65.21 \%$ & $65.21 \%$ & $65.21 \%$ \\
\hline Reduced distances travelled $(-20 \%)$ & $16.76 \%$ & $16.69 \%$ & $16.71 \%$ & $16.70 \%$ & $16.71 \%$ & $16.72 \%$ & $16.71 \%$ & $16.70 \%$ & $16.71 \%$ \\
\hline
\end{tabular}

renovation rate, $31.23 \%$ if doubling this current renovation rate, $44.41 \%$ and $88.82 \%$ with a light or heavy renovation of the entire building stock, respectively. The application of the photovoltaic scenario $\left(20 \mathrm{~m}^{2}\right.$ of PV panels on each residential building) will allow an average reduction of $9.26 \%$ in non-renewable energy consumption for the Walloon residential building stock for the reference year (2012). Transport energy consumption in 2040 could be reduced by $65.21 \%$ with $100 \%$ electric cars, $33.26 \%$ with $50 \%$ electric cars, and $16.78 \%$ following a $20 \%$ reduction for all distances travelled. The detailed reduction frequencies in energy consumption by neighbourhood class are shown in Table 9.

However, we remind you that all the scenarios studied can lead to considerable savings in the energy bill. It is in this sense that in subsection 4.6, we present the most effective scenarios, constructed from a combination of the previous scenarios. According to the European commission, building renovation makes it possible to save energy up to $50 \%$ [70]. The results found in this study are in agreement with this conclusion.

\subsection{Mixed scenarios}

After elaborating the four previous scenarios, we now realize scenarios resulting from the addition of several options and calculate the total consumption of different neighbourhood classes by 2040. First, we consider year 2040 for the number of degree days, and based on this consumption, we will determine the consumption of each neighbourhood class using a combination of different hypotheses such as light or heavy renovations, installation of photovoltaic panels, changes in

Table 10

Reduction (in percentage) in total energy consumption (buildings + transport - local renewable energy) based on mixed scenarios applied on the Walloon building stock, per neighbourhood class.

\begin{tabular}{|c|c|c|c|c|c|c|c|c|c|}
\hline & \multicolumn{9}{|c|}{ Types of neighbourhoods in the Walloon building stock in Belgium. } \\
\hline & 1 & 2 & 3 & 4 & 5 & 6 & 7 & 8 & 9 \\
\hline \multicolumn{10}{|c|}{ Total energy consumption of each neighbourhood class of residential building stock in Wallonia (Belgium) in 2012} \\
\hline Control scenario (GWh) & 34.13 & 73.31 & 151.06 & 305.49 & 667.09 & 1201.35 & 5384.97 & $33,455.53$ & 8365.51 \\
\hline \multicolumn{10}{|c|}{$\begin{array}{l}\text { Rate of reduction of total energy consumption (buildings }+ \text { transport - new local renewable energy) of each neighbourhood class in the residential building stock in } \\
\text { Wallonia (Belgium) by } 2040 \text { (compared to the control scenario in 2012) }\end{array}$} \\
\hline Mixed Scenario 1 & $18.31 \%$ & $18.28 \%$ & $18.83 \%$ & $18.25 \%$ & $18.36 \%$ & $19.00 \%$ & $22.49 \%$ & $22.39 \%$ & $22.22 \%$ \\
\hline Mixed Scenario 2 & $63.9 \%$ & $63.92 \%$ & $63.93 \%$ & $63.86 \%$ & $63.92 \%$ & $64.33 \%$ & $67.64 \%$ & $67.46 \%$ & $66.65 \%$ \\
\hline Mixed Scenario 3 & $35.16 \%$ & $35.16 \%$ & $35.53 \%$ & $35.15 \%$ & $35.17 \%$ & $36.11 \%$ & $39.21 \%$ & $39.08 \%$ & $36.63 \%$ \\
\hline Mixed Scenario 4 & $27.86 \%$ & $27.81 \%$ & $28.39 \%$ & $27.82 \%$ & $27.92 \%$ & $28.48 \%$ & $30.86 \%$ & $30.54 \%$ & $27.80 \%$ \\
\hline Mixed Scenario 5 & $36.5 \%$ & $36.28 \%$ & $36.88 \%$ & $36.13 \%$ & $36.22 \%$ & $36.38 \%$ & $38.32 \%$ & $37.64 \%$ & $34.51 \%$ \\
\hline Mixed Scenario 6 & $37.00 \%$ & $36.98 \%$ & $37.58 \%$ & $37.00 \%$ & $37.09 \%$ & $37.58 \%$ & $39.89 \%$ & $39.15 \%$ & $36.25 \%$ \\
\hline Mixed Scenario 7 & $44.85 \%$ & $44.697 \%$ & $45.19 \%$ & $44.54 \%$ & $44.24 \%$ & $45.05 \%$ & $46.64 \%$ & $45.94 \%$ & $43.28 \%$ \\
\hline Mixed Scenario 8 & $72.55 \%$ & $72.39 \%$ & $72.42 \%$ & $72.03 \%$ & $72.24 \%$ & 72.49 & $75.10 \%$ & $74.16 \%$ & $73.35 \%$ \\
\hline Mixed Scenario 9 & $91.20 \%$ & $91,09 \%$ & $91.17 \%$ & $90.95 \%$ & $90.97 \%$ & $91.06 \%$ & $91.50 \%$ & $90.92 \%$ & $90.62 \%$ \\
\hline
\end{tabular}




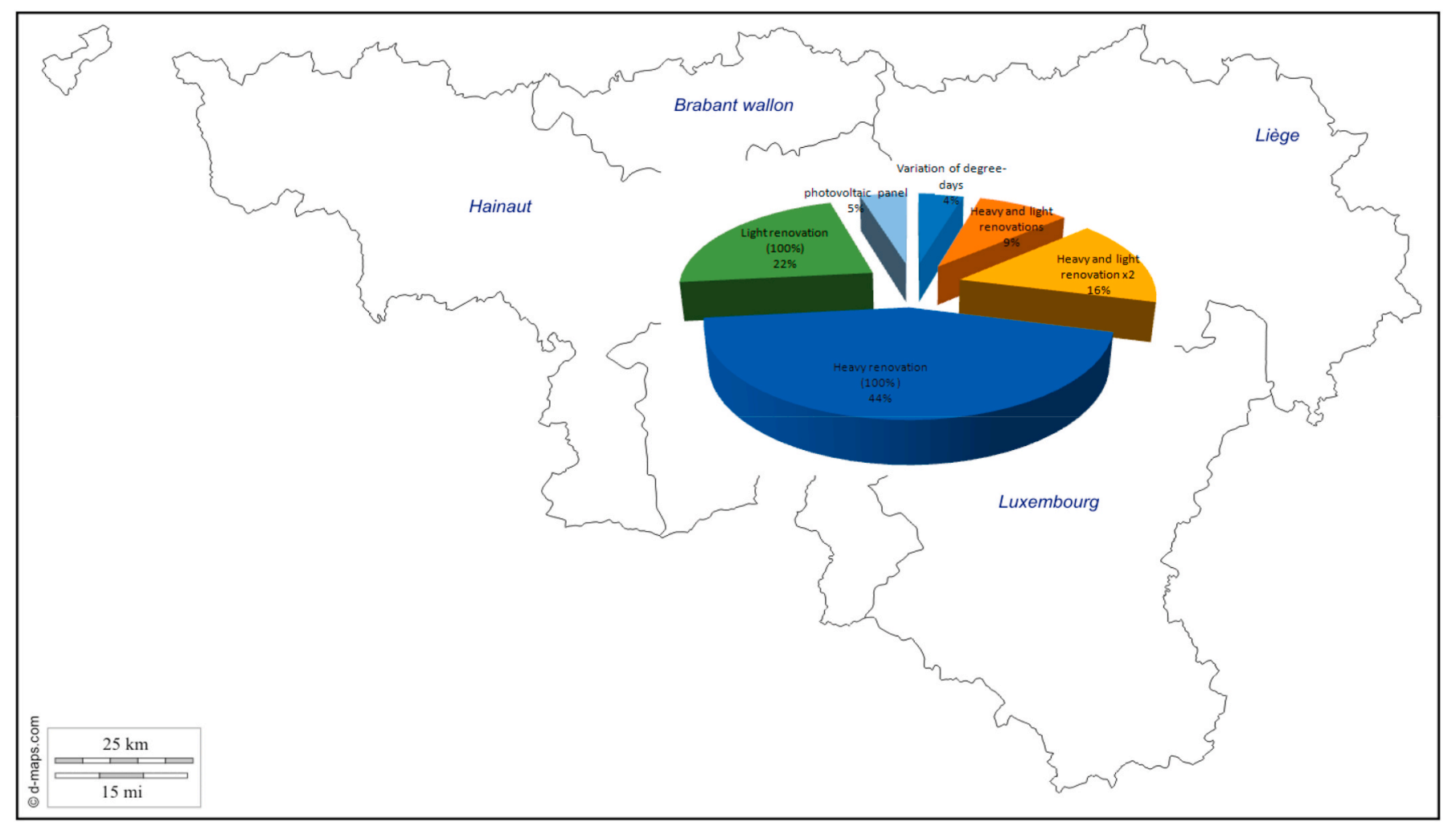

Fig. 3. Global reduction in residential energy consumption (buildings) by different scenarios in Wallonia, Belgium.

number of electric cars in a car park, and reduction in distances travelled. We present nine scenarios and select those that are most appropriate for the neighbourhood classes.

The results of these combined scenarios are presented in Table 10. First, Table 10 provides reference values for the control scenario by considering the energy consumed by housing and for displacements in 2012. Next, we developed the following nine new scenarios:

1/First mixed scenario: Global warming + heavy and light renovations according to current renovation rate +current transport;

2/Second mixed scenario: Global warming + heavy renovations of all buildings + current transport;

3/Third mixed scenario: Global warming + light renovations of all buildings + current transport;

4/Fourth mixed scenario: Global warming + heavy and light renovations according to current renovation rate $+50 \%$ electric cars.

5/Fifth mixed scenario: Global warming + heavy and light renovations according to current renovation rate $+50 \%$ electric cars - solar panels.

6/Sixth mixed scenario: Global warming + heavy and light renovations according to current renovation rate $+100 \%$ electric cars.

$7 /$ Seventh mixed scenario: Global warming + doubling the current renovation rate of heavy and light renovations $+50 \%$ electric car transport - solar panels.

8/Eighth mixed scenario: Global warming + heavy renovation of all buildings (100\%) + current transport -solar panels.

9/Ninth mixed scenario: Global warming + heavy renovation of all buildings $(100 \%)+100 \%$ electric cars - solar panels.

Next, we calculated the total energy consumption for the previously established scenarios, thanks to the following formula: energy consumption due to buildings + energy consumption due to transport local renewable energy. Finally, we evaluated the reduction (in percentage) in total energy consumption following the 9 mixed scenarios for the nine neighbourhood classes. Based on these applications, we obtained the total consumption of each neighbourhood class according to the mixed scenarios, and this allows us to determine which scenarios are the most conclusive, or conversely, the least efficient.

Scenario 9 (global warming heavy renovation $100 \%+100 \%$ electric cars - solar panels)is the best of all the nine scenarios; indeed, on average, it allows to reduce up to $91.5 \%$ of total energy consumption in 2040 in the Wallonia neighbourhoods, compared to the reference year. Scenario 2, taking into account the phenomenon of global warming, heavy renovations of all the buildings and current energy consumption for transport, Scenario 8, taking into account the same scenario with additional solar panels, already provide very good results, with a reduction corresponding on average to two-thirds and three-quarters of the initial global energy consumption (buildings + transport) of the residential building stock in Wallonia, respectively. Scenario 9 is the only scenario that achieves nearly zero-energy at the neighbourhood scale, considering energy consumption by buildings and daily mobility.

\section{Discussions}

The majority of current studies that are based energy efficiency and zero energy were regularly carried out at the building scale [12-14]. We want to broaden the reflection at the neighbourhood level because it is clear that environmental issues in future will be resolved at the urban scale. We believe that this type of approach is the logical continuation of current regulations. Fig. 3 shows global reduction in energy consumption (\%) due to several scenarios implemented at the neighbourhood scale, accounting for energy consumption in buildings and the transport sector.

The average reduction in energy consumption of neighbourhoods (buildings + daily mobility) at the regional scale in Wallonia (Belgium) in 2040 (compared to 2012) will reach 5.69\% following a 20\% reduction in distances travelled, $6.48 \%$ due to degree-days evolution, $9.57 \%-50 \%$ of electric cars, $12.95 \%$ to the current annual buildings renovation rate, $18.76 \%-100 \%$ electric cars, $22.26 \%$ due to doubling the current buildings renovation rate, $31.62 \%$ and $63.25 \%$ following a light or heavy renovation of entire building stock, respectively. Moreover, adding 20 $\mathrm{m}^{2}$ of solar panels on the rooftops of each residential building would 
Table 11

Global reduction in energy consumption (buildings + transport- solar energy) by mixed scenario in 2040 (compared to 2012 ) in Wallonia, Belgium.

\begin{tabular}{|c|c|c|c|c|c|c|c|c|c|}
\hline Scenario & Mix 1 & Mix 2 & Mix 3 & Mix 4 & Mix 5 & Mix 6 & Mix 7 & Mix 8 & Mix 9 \\
\hline Reduction rate & $22 \%$ & $66 \%$ & $38 \%$ & $30 \%$ & $37 \%$ & $39 \%$ & $45 \%$ & $74 \%$ & $91 \%$ \\
\hline
\end{tabular}

produce renewable energy equivalent to $6.53 \%$ of this global energy consumption for buildings and daily mobility (transportation). Some mixed scenarios have also been tested. Table 11 shows the global reduction in energy consumption related to these mixed scenarios, accounting for buildings and daily mobility at the regional scale.

It is important to emphasize that the main objective of all these scenarios was to propose techniques for reducing energy in buildings and transportation. The results show that a scenario involving the influence of the global warming, a heavy renovation of the entire residential buildings stock, a massive integration of electric cars (to reach $100 \%$ ) and installing solar panels on rooftops are imperative to achieving a nearly zero energy goal at the neighbourhood scale. Moreover, due to poor energy performance of a major part of the actual buildings stock in Wallonia, heavy renovation of the entire residential buildings stock in a neighbourhood is always the most efficient solution to reducing global energy consumption.

Roof correction factors, accounting for the shadowing effect between buildings, have a significant impact on photovoltaic panel production in a neighbourhood. It was observed that the shadowing effect was much higher in the urban region. Nevertheless, this difference in the production of solar energy, following the neighbourhood type, does not seem to change energy priorities and strategies for the regional scale.

Indeed, more than $80 \%$ of residential buildings are more than 100 years old in Wallonia; thus, among the different scenarios applied in the nine neighbourhood's categories, it is noticed that heavy renovations within buildings are the most effective levers of action to decrease energy consumption. These findings were found to be similar to other studies conducted at the urban scale of Liège [51] and at the national scale [64], showing that building renovation is the most efficient method for reducing energy consumption in Belgium. Increasing the energy performance of buildings through heavy renovations or sustainable design reduces their overall environmental impact $[65,66]$. This may be possible by designing the building envelope with materials and techniques adapted to climate change [67].

Finally, working on a more sustainable mobility method and integration of local renewable energy sources are complementary strategies that remain useful to achieve the zero-energy target. These conclusions are consistent with those of previous studies on the same topics $[22,68]$.

\section{Conclusion}

The study shows that it is possible to estimate the current levels of energy consumption in the Walloon region of Belgium and propose several strategies to reduce consumption. Analysing data for the nine neighbourhood categories that are typically representative of the region, we have quantified energy consumption in buildings and commuting and created scenarios to reduce them. By studying four main scenarios and nine mixed scenarios, we highlighted the most effective levers of action at the neighbourhood scale. These investigations also highlighted the poor insulation of buildings in the Walloon region, due to an old housing stock. During the construction of most of these buildings, energy consumption was not considered a priority. Today, these aging buildings have lost their state of energy performance, so that light and heavy renovation techniques have the greatest impact on household energy consumption. However, a combination of these measures with others, such as installation of photovoltaic panels, reducing distances travelled, or increasing electric vehicles, would improve this reduction. The conclusions drawn from this research may help local stakeholders to develop better energy policies to reduce energy consumption in the Walloon region. The same conclusions are applicable to other European countries with the same climate and type of building stock.

Note that the installation of photovoltaic panels is most adapted in rural and peri-urban areas, while in urbanized areas this method is less productive because of the shadow effect. On the contrary, increasing the number of electric vehicles (cars, trains, trams) in a city is a good way to reduce energy consumption.

Nevertheless, additional studies are necessary to complete and specify the results obtained, for example accounting for socio-economic constraints. Another study could focus on cost optimization by considering the principles set by the European conventions on the energy performance of buildings. Finally, the adapted approach in research related to zero-energy neighbourhoods differentiates according to the places studied. This research was conducted by issuing several hypotheses used in research studies in Belgium. It would be interesting to compare the results if other assumptions or other climatic and regional characteristics were used.

\section{Declaration of competing interest}

The authors declare that they have no known competing financial interests or personal relationships that could have appeared to influence the work reported in this paper.

\section{Acknowledgments}

The authors acknowledge AXA Company for its financial support, and the LEMA laboratory team at the University of Liege where this study was conducted.

\section{References}

[1] Nematchoua MK, Yvon A, Roy SAJ, Ralijaona CG, Mamiharijaona R, Razafinjaka JN, Tefy R. A review on energy consumption in the residential and commercial buildings located in tropical regions of Indian Ocean: a case of Madagascar island. J Energy Storag 2019;24:100748.

[2] recast EPBD. Directive 2010/31/EU of the European Parliament and of the Council of 19 May 2010 on the energy performance of buildings (recast). Off J Eur Union 2010;3:41. . [Accessed 13 March 2019].

[3] Beccali M, Cellura M, Fontana M, Longo S, Mistretta M. Energy retrofit of a singlefamily house: life cycle net energy saving and environmental benefits. Renew Sustain Energy Rev 2013;27:283-93.

[4] Kalz E, Pfafferott J, Herkel S. Building signatures: a holistic approach to the evaluation of heating and cooling concepts. Build Environ 2010;45(3):632-46.

[5] Chlelaa F, Husaunndeeb A, Inardc C, Riederera P. A new methodology for the design of low energy buildings. Energy Build 2009;41(9):982-90.

[6] Santamouris M, Kolokotsa D. Passive cooling dissipation techniques for buildings and other structures, the State of the Art. Energy and Build 2013;57:74-94.

[7] Pfafferott J, Herkel S, Wambsganß M. Design, monitoring and evaluation of a low energy office building with passive cooling by night ventilation. Energy Build 2004;36(5):455-65.

[8] Neves AR, Leal V. Energy sustainability indicators for local energy planning: review of current practices and derivation of a new framework. Renew Sustain Energy Rev 2010;14(9):2723-35. https://doi.org/10.1016/j.rser.2010.07.067.

[9] Yamagata Y, Seya H. Simulating a future smart city: an integrated land use-Energy model. Appl Energy 2013;112:1466-74. https://doi.org/10.1016/j. apenergy.2013.01.061.ISSN:0306-2619.

[10] Kumar P, Geneletti D. How are climate change concerns addressed by spatial Plans? An evaluation framework, and an application to Indiancities. Land Use Pol 2015;(42):210-26. https://doi.org/10.1016/j.landusepol.2014.07.016.ISSN:02648377.

[11] United States Department of Energy (US DOE) Building Technologies Program. Planned program activities for 2008-2012. 2008. p. 1. Washington DC6.

[12] Marszal AJ, Heiselberg P, Bourrelle JS, Musall E, Voss K, Sartori I, Napolitano A. Zero energy building - a review of definitions and calculation methodologies. Energy Build 2011;43:971-9.

[13] Voss K, Musall E, Lichtmes M. From low-energy to net zero-energy buildings: status and perspectives. J Green Build 2011;6:46-57.

[14] Sartori I, Napolitano A, Voss K. Net zero energy buildings: a consistent definition framework. Energy Build 2012;48:220-32. 
[15] Mohamed A, Hasan A, Sirén K. Fulfillment of net-zero energy building (NZEB) with four metrics in a single family house with different heating alternatives. Appl Energy 2014;114:385-99.

[16] Voss K, Musall E. Net zero energy buildings. International projects of carbon neutrality in buildings. Munich: Institut für international ArchiteckturDokumentation, GmbH \& CO.KG; 2011. p. 192p.

[17] Attia S, Gratia E, De Herde A, Hensen JLM. Simulation-based decision support tool for early stages of zero-energy building design. Energy Build 2012;49:2-15.

[18] Yu T. A novel system solution for cooling and ventilation in office buildings Are view of applied technologies and a case study. Energy Build 2015;90:142-55.

[19] Gago EJ, Muneer T, Knez M, et al. Natural light controls and guides in buildings. Energy saving for electrical lighting, reduction of cooling load. Renew Sustain Energy Rev 2015;41:1-13.

[20] IEA.Net. Zero energy solar buildings. International energy agency: solar heating and cooling programme. 2014. . [Accessed 25 June 2019].

[21] Voss K, Musall E. Net zero energy buildings - international projects of carbon neutrality in buildings. second ed. München: Institut für internationale Architektur-Dokumentation; 2012. p. 1. 32Mars18, 2019.

[22] Marique AF, Reiter S. A simplified framework to assess the feasibility of zeroenergy at the neighbourhood/community scale. Energy Build 2014;82:114-22.

[23] Torcellini P, Pless S, Deru M. National renewable energy laboratory, zero energy buildings: a critical look at the definition. In: Conference paper NREL/CP-55039833, vol. 20; 2006. p. 5. February 10, 2019.

[24] Brown HS, Vergragt PJ. Bounded socio-technical experiments as Agents of systemic change: the case of a zero-energy residential building. Technol Forecast Soc Change 2008;75:107-30.

[25] Yi H, Srinivasan RS, Braham WW, Tilley DR. An ecological understanding of netzero energy building: evaluation of sustainability based on emergy theory. J Clean Prod 2017;143:654-71.

[26] Szalay Z, Zöld A. Definition of nearly zero-energy building requirements based on a large building sample. Energy Pol 2014;74:510-21.

[27] Zhou Z, Feng L, Zhang S, Wang C, Chen G, Du T, Li Y, Zuo J. The operational performance of "net zero energy building ": a study in China. Appl Energy 2016; 177:716-28.

[28] Srinivasan RS, Braham WW, Campbell DE, Curcija CD. Re(De) fining net zero energy : renewable emergy balance in environmental building design. Build Environ 2012;47:300-15.

[29] Robert A, Kummert M. Designing net-zero energy buildings for the future climate, not for the past. Build Environ 2012;55:150-8.

[30] Chastas P, Theodosiou T, Bikas D. Embodied energy in residential buildingstowards the nearly zero Energy building: a literature review. Build Environ 2016; 105:267-82.

[31] Annunziata E, Frey M, Rizzi F. Towards nearly zero-energy buildings: the state-ofart of national regulations in Europe. Energy 2013;57:125-33.

[32] Li DHW, Yang L, Lam JC. Impact of climate change on energy use in the built environment in different climate zones: are view. Energy 2012;42:103-12.

[33] Kurnitski J, Saari A, Kalamees T, Vuolled M, Niemeläd J, Tark T. Cost optimal and nearly zero (nZEB) energy performance calculations for residential buildings with REHVA definition for nZEB national implementation. Energy Build 2011;43: 3279-88.

[34] Pikas E, Thalfeldt M, Kurnitski J. Cost optimal and nearly zero energy building solutions for office buildings. Energy Build 2014;74:30-42.

[35] Todorovic MBPS. Energy efficiency and renewable energy sources for buildings greening and zero energy cities planning. Energy Build 2012;48:180-9.

[36] Zeiler W, Boxem G. Net-zero energy building schools. Renew Energy 2013;49: 282-6.

[37] Lopes RA, Martins J, Aelenei D, Lima CP. A cooperative net zero energy community to improve load matching. Renew Energy 2016;93:1-13.

[38] Garde F, Lenoir A, Scognamiglio A, Aelenei D, Waldrend D, Rostvike Ayou J, Aelenei L, Donn M, Tardif M, Cory S. Design of net zero energy buildings: feedback from international projects. Energy Procedia 2014;61:995-8.

[39] Kylili A, Fokaides PA. European smart cities: the role of zero energy buildings. Sustain Cities and Soc 2015;15:86-95.

[40] Ala-Juusela M, Crosbie T, Hukkalainen M. Defining and operationalising the concept of an energy positive neighbourhood. Energy Convers Manag 2016;125: $133-40$.

[41] Koch A, Girard S, McKoen K. Towards a neighbourhood scale for low- or zerocarbon building projects. Build Res Inf 2012;40:527-37.

[42] He D, Huang S, Zuo W, Kaiser R. Towards to the development of virtual te Stbed for net zero Energy communities. ASHRAE and IBPSA, USA, SimBuild 2016, building performance modeling conference salt lake city. 2016. UT August 8-12.
[43] Hachem C, Athienitis A, Fazio P. Evaluation of energy supply and demand in solar neighborhood. Energy Build 2012;49:335-47.

[44] Burch J, Woods J, Kozubal E, Boranian A. Zero energy communities with central solar plants using liquid desiccants and local storage. Energy Procedia 2012;30: 55-64.

[45] Compagnon R. Solar and daylight availability in the urban fabric. Energy Build 2004;36:321-8.

[46] Kennedy S, Sgouridis S. Rigorous classification and carbon accounting principles for low and zero carbon cities. Energy Pol 2011;39:5259-68.

[47] Newman P, Kenworthy K. Gasoline consumption and cities - a comparison of UK cities with a global survey. J Am Plann Assoc 1989;55:24-37.

[48] Banister D. Energy use transport and settlement patterns. In: Breheny M, editor. Sustainable development and urban form. London: Pion Ltd.; 1992. p. 160-81.

[49] Naess P, Sandberg S, Roe PG. Energy use for transportation in 22 nordic towns. Scand Hous Plann Res 1996;13:79-97.

[50] Boarnet M, Crane R. Travel by design. The influence of urban form on travel. NewYork: Oxford University Press; 2001.

[51] Reiter S, Marique AF. Toward low energy cities : a case study of the urban area of Liège, Belgium. J Ind Ecol 2012;16(6):829-38.

[52] Marique AF, Dujardin S, Teller J, Reiter s. School commuting: the relationship between energy consumption and urban form. J Transport Geogr 2013;26:1-11.

[53] Marique AF, Dujardin S, Teller J, Reiter s. Urban sprawl, commuting and travel energy consumption. Proc Inst Civ Eng: Energy 2013;166(1):29-44.

[54] Marique AF, De Meester T, De Herde A, Reiter S. An online interactive tool to assess energy consumption in residential buildings and for daily mobility. Energy Build 2014;78:50-8.

[55] CEHD. Enquête sur la qualité de l'habitat en Wallonie - Résultats clés. 2014. . [Accessed 10 April 2019].

[56] Marique A-F, de Meester T, Cuvellier S, De Herde A, Reiter S. Solen - solutions for low energy neighborhoods : scientific and technical report. Liège, belgique: université de Liège. 2015. Mars 15,2019.

[57] Marique A-F, Cuvellier S, De Herde A, Reiter S. Assessing household energy uses: an online interactive tool dedicated to citizens and local stakeholders. Energy Build 2017;151C:418-28.

[58] ICEDD. Bilan énergétique de la Wallonie 2014_Secteur domestique et équivalents. 2014. p. 1. 21Mars $15,2019$.

[59] Pacot P-E, Reiter S. Evaluation du besoin de cogénération en Belgique dans la perspective des plans 2020-2030. Rapport Scientifique et Technique; 2012. p. 4. 9, . [Accessed 15 March 2019].

[60] Ruellan G. Etat du marché de la rénovation du Bâti résidentiel en Belgique. Société Wallonne du Logement 2016;5(15).

[61] Teller J, Azar S. Townscope II- a computer system to support solar access decisionmaking. Sol Energy 2001;70:187-200.

[62] Hubert M, Huynen P, Lebrun K, Patriarche G, De Witte A, Creemers L, Declercq K, Janssens D, Castaigne M, Hollaert L, Walle F. La Mobilité en Belgique, resultants de l'enqueteBELDAM, vol. 1. Book; 2010. 352.

[63] Boussauw K, Witlox F. Introducing a commute-energy performance index for Flanders. Transport Res Part A 2009;43(5):580-91.

[64] Attia S, Mlecnik E, Van Loon S. Principles for nearly zero energy building in Belgium. World sustainable energy days, vol. 5; 2012. 15Mars 10, 2019.

[65] Nematchoua MK, Teller J, Reiter S. Statistical life cycle assessment of residential buildings in a temperate climate of northern part of Europe. J Clean Prod 2019; 229:621-31.

[66] Nematchoua MK, Reiter S. Analysis, reduction and comparison of the life cycle environmental costs of an eco-neighborhood in Belgium. Sustain Cities and Soc 2019;48(9):1.

[67] Nematchoua MK, Yvon A, Kalameu O, Choudhary R, Reiter S. Impact of climate change on demands for heating and cooling energy in hospitals: an in-depth case study of six islands located in the Indian. Ocean region Sustain Cities and Soc 2019; 44:629-45.

[68] Nematchoua MK, Reiter S. Energy consumption assessment due to the mobility of inhabitants, and multiannual prospective on the horizon 2030-2050. A case of Belgium, Energy 2019;171:523-34.

[69] Nematchoua MK, Caroline D, Mario C, Sigrid R. Evaluation of the potential of classic and electric bicycle commuting as an impetus for the transition towards environmentally sustainable cities: a case study of the university campuses in Liege, Belgium. Renew Sustain Energy Rev 2020;119:109544.

[70] European commission. Available online: https://ec.europa.eu/easme/en/news/bui lding-renovation-makes-it-possible-save-energy-50 (accessed on June 24, 2020). 